\title{
RURAL SAVINGS MOBILIZATION AND AGRICUTURAL PRODUCTION IN THE SOUTHERN ZONE OF ABIA STATE, NIGERIA
}

GABRIEL S. UMOH and ADEMOLA A. AZEEZ

(trae (Received 16 December 1999, Revision accepred 9 March 2000)

\begin{abstract}
This study examined savings mobilization techniques and agricultural production in Ukwa East Local Government Area, southern zone of Abia State, Nigeria. Drawing from a sample of 85 farmers, findings revealed that $36.47 \%$ of the farmers saved their money in local clubs (Osusu), 23.53\% in cooperative societies and $21.12 \%$ in the banks. Among crop farmers, those who saved in the Co-operative societies had the highest output per person ( 316.7 tons), while the livestock farmers saving in bank had the highest output per person. Regression analysis showed that with the exception of distance to savings institutions, other variables (annual income, farming/non-farming expenditure and household size) significantly influenced total annual household savings ( $P<0.01$ and 0.05 , respectively).
\end{abstract}

Key Words: Rural Savings, Mobilization, Agricultural Production, Nigeria.

\section{INTRODUCTION}

It has become a well-established fact that the bulk of agricultural production in Nigeria is made by the rural farmers. Also, the bulk of agricultural exports are a collection of the production from these rural farms which are scattered all over the country. Despite ru.ai farmers' production and contributions to the economy, their individual production level has been confirmed to still remain low. This has been attributed to their low savings and income levels.

Scholars have agreed that increased agricultural productivity is a function of the income and expenditure of the farmers. It is the position of Ojo and Osakwe (1984), and Umoh (1998), that increased agricultural productivity must necessarily require adequate accumulation of capital to assist in the structural transformation of the economy through

investments in basic infrastructure and other capital projects. Inspite of this generally accepted fact, savings mobilization by rural dwellers, particularly rural farmers, in developing countries (Nigeria inclusive) has remained an uphill task. Iniodu and Ukpak (1996) argued that since most of the rural, dwellers rarely live above the subsistence level, the rate of voluntary saving is absymally low and the mobilization of savings under such conditions is difficult.
Olayide et al (1979) had earlier maintained that the conservative factors, in addition to the farm problem and growing population, fixed land asset, declining potential of productive resources, static technology and low capitalisation lead to low production level, low income and capital accumulation. The low capital accumulation of the ruralities has been attributed to their dependence on their lean sources of investible funds-personal savings, friends and relatives and other traditional financial institutions such as etibe (Ibibio), esusu (Yoruba), adashi (Tiv), etc. (Umoh, 1998), whose contribution do not meet the financial needs of rural dwellers (ljere, 1992).

Given the crucial role of capital formation in sustainable development, successive Nigerian administrations have tried to diversify the rural savings mobilization methods through the establishment of savings institutions. These include the Post Office Savings Scheme, the Rural Banking Scheme (1977), the People's Bank (1989) and the Community Banking Scheme (1990). The present study was designed to ascertain the effect of savings methods on agricultural production in Ukwa East Local Government Area of Abia State, Nigeria. In order to achieve the above general objective, the following specific objectives were pursued;

(i) to identify the rural savings mobilization techniques of the farmers in Ukwa East Local Government Area of Abia State. 
(ii) to assess the relationship between the farmers' sociocconomic characteristics and their savings methods; with the aim of identifying factors that influence savings;

(iii) to examine the relationship between savings methods and agricultural production in the study area; and

(iv) based on the findings of the study, to offer policy recommendations that will enhance savings mobilization and ultimately increase agricultural production

The rest of the paper is organized as follows: In section II, we provide a brief overview of the theoretical linkages between savings mobilization and production. Section III presents the methodology while Section IV. concludes the paper and offers some suggestions.

\section{THEORRTICAL ISSUES}

The link betweern capital accurnulation and production is a strong onc. The traditional growth model with separate factors of production (Ramscy, 1928; Solow, 1956; Cass, 1965; Koomans, 1965; and Barro and Sala-i-Martin 1990, 1991), predicts that output can only grow through increased factor accumulation and/or through technical progress. However, factor accumulation, cspecially capital can esscntially come about through savings. The Keyncsian Concept has established the relation botwcen income-savings and investment growth. Harrod-Dommer growth theory shows dircctly the influence of money on growth, since it relates the ratio of savings to capital-output ratio as the determinant of economic growth. This is represented mathematically as:

$$
\mathrm{g}=\mathrm{S} / \mathrm{V}
$$

Where $g$ is the economic growth, $S$ refers to savings rate while $\mathrm{V}$ is incremental capitaloutput ratio. This implies that economic growth can be achieved by increasing savings rate with constant capital-output ratio or lowering the latter with the former remaining constant. Applied to the agricultural sector, this means that agricultural output would increase through increased savings. The ncoclassical cconomic thcory shows that savings rate is a necessary condition for capital accumulation and economic growth in the short run. An increase in savings increases the ratio of capital stock to the given labour supply and initially raises the growth rate of output per capital. Thus, "the multiplier effects of savings in the rural area would, be tremendous" (Tella, 1998).

Experts have acknowledged and widely documented the role of financial institutions in the accumulation of savings and provision of credits for investment through their intermediation proccsses (Patrick, 1966; Portcr, 1966). It is these institutions that mobilize funds from surplus arcas and channel them to deficit units, thus ensuring, efficient allocation of funds for investinent purposes. Pooling of funds by financial intermediaries makes it possible for relatively indivisible large projects to be undertaken and thereby makes funds available to entrepreneurs, whose talents would otherwise remain untapped. and who have to pay competitive inierest rates for the use of funds. This procedure ensures that projects undertaken tend to be more productive than those which savers would undertake in the absence of intermediation (Mlambo and Elhiraika, 1997).

\section{METHODOLOGY}

\subsection{THE STUDY AREA:}

This study was carried out in Ukwa East Local Government Area (L.G.A.) of Abia State, Nigeria. The area is located in the Southern Zone of Abia State and is made up of ten clans each comprising four villages. It shares boundaries with neighbouring Local Government Arcas of Chioma Ngwa and Ukwa-West, respectively and the neighbouring states of Rivers and Akwa lbom.

The major occupation of the people is farming and trading while a few are Civil Servants. Crops grown include staples such as cassava, yam, maize and vegetables and tree crops such as oil palm, plantain, citrus and coconut.

\subsection{DATA COLLECTION}

The data used in this study were collected principally from primary sources. The main instrument was structured questionnairc. The study population comprised farmers in the Local Government Area. A sample size of eighty-five farmers, selccled randomly from 10 villages out of the twenty which make up the Local Government Area, was employed in the analysis.

Multi-stage sampling tcchnique was used in selecting the sample. The first involved random selection of ten villages from the list of twenty. From the sampled villages, the simple random sampling method was then used to select eightyfive (85) farmers

Ten farm households were randomly selected from each of the villages for study. The questionnaires were distributed equally to the ten villages. The farmers were interviewed and their responses filled into the questionnaire. Literate farmers were allowed to complete the questionnaires by themselves. Eighty five (85) of the questionnaires were completed with useable information and were thus used for analysis.

\subsection{ANALYTICAL TECHNIOUES}

Simple techniques of percentages, proportions and frequency count were employed in analysing the data. To verify the relationship between savings and other variables, the least square techniques of multiple regression analysis was used.

The implicit form of the model is 
specificd as:

$$
S=I(A l, H S, D S I, F N E)
$$

Where:

$\mathrm{S}=$ Total annual household Savings

$\mathrm{AI}=$ Annual lncome (in Naira)

HS = Houschold size (Number of persons)

DSI = Distance of savings inst ation (in Kilometer)

FNE=Farming/Non-farming expenditure (in Naira)

The estimated form of the equation is:

$S=a_{0}+a_{1} A I+a_{2} H S+a_{2} D S I+a_{4} F N L+u i$

All the variables are as defined earlier

$a_{0}=$ constant term

$a_{1}-a_{4}=$ Coefficients of the variables

ui $=$ Stochastic error term to be estimated.

Four functional forms of the above equation were tried for exploratory purpose. These were linear, semi-log, double-log and exponential functions. The double-log function was selected as equation of "best fit". The selection of the lead equation was based on economic, statistical and econometric justification namely; the sign and magnitude of the coefficients; the size of $R^{2}$, the $t$-test and Ftest values and the error term.

The coefficients of annual income ( $A$ i), is expected a priori to be positively signed. This is because, all other things being equal, a higher annual income should increase houscholds' savings. The cocflicionts of distance of savings institution (DSI) and farming/non-farming expenditure (FNE) would be negatively signed. It is expected that proximity to a saving institution would encourage farmers to save. Similarly, increased farming/non-farming expenditure is likely to reduce savings. Howcter. the coefricient of houschold size (HS) conld be either positively or negatively signed. A large houschold size is expected to consume more from the houscliold income. This could make savings and houschold size to be inversely related. On the other hand, if the houschold members contribute to the pool of household income, this should increase the total houschold income and all other things being equal, translates into increased savings.

\section{RESULTS AND DISCUSSION \\ 4.I SAVINGS MOBILIZATION TECHNIOUES}

Savings mobilization techniques were considered with respect to available linancial institutions, both formal and informal, operating within the grea and how the rolate: avings behaviour of the people. Tine arable techniques used in the study area include the local clubs (Osusu), co-opcrative societics, banks and others including kecping money with frionds/relatives, under pillows and personal safe.

Table 1 shows the utilization of these methods by respondevis. Sixloen (18.8 percent) of the respondents used some techniques other than those specified, securing the highest amount :r person (N5,055.83). These other techniques include personal safe, saving under pillows, keeping with relatives and friends, elc. This indicates that much money is kept outside the recogniscd savings institulions.

The local clubs (Osusu) came next with 31 (36.74 percent) respondents, saving a total of N150,720.00 yearly and N4.861.94 per person. The Osusu mobilized about 43 percent of total savings from all sources. Co-operative societies had $\mathrm{N} 94,100.00$ from 20 (23.6 percent) of the respondents at $\mathrm{N4,705,00}$ per person. This is low going by the advantages of these societies to its

\section{TABLE 1: MOBILIZATION TECHNIQUES AND SAVINGS POTENTIALS}

\begin{tabular}{|c|c|c|c|c|c|c|}
\hline S/no & Techniques & $\begin{array}{l}\text { No. of } \\
\text { Farmers }\end{array}$ & $\begin{array}{l}\text { Percentage } \\
(\%)\end{array}$ & $\begin{array}{l}\text { Total } \\
\text { Savings } \\
\text { (N) }\end{array}$ & $\begin{array}{l}\text { Savings } \\
\text { per person } \\
(\mathrm{N})\end{array}$ & $\begin{array}{l}\text { Percentage } \\
\text { of Savings } \\
\text { Mobilized } \\
\text { per sour }\end{array}$ \\
\hline 1. & $\begin{array}{l}\text { Local Club } \\
(\text { Osusu) }\end{array}$ & 31 & 36.47 & 150,700 & $4,861.94$ & 42.90 \\
\hline 2. & $\begin{array}{l}\text { Co-operative } \\
\text { Societies }\end{array}$ & 20 & 23.53 & 94,100 & $4,705.00$ & 26.79 \\
\hline 3. & Banks & 18 & 21.18 & 45,800 & $2,544.44$ & 13.04 \\
\hline 4. & Others & 16 & 18.82 & 60,670 & $5,055.83$ & 17.27 \\
\hline \multicolumn{2}{|c|}{ TOTAL } & 85 & 100.00 & 351,790 & $17,167.21$ & 100.00 \\
\hline \multicolumn{2}{|c|}{ MEAN SAVINGS } & - & - & $4,132.82$ & - & \\
\hline
\end{tabular}


N2,544.44 per person. Non-formal savings institutions like 'Osusu' are those formed by the rural people in lieu of formal savings institutions. This study has therefore, confirmed the assertion that due to the fact that financial intermediation has not been saving oriented, the largest part of the savings originated by middle and lower income groups is to be found in non-organized financial sector. Since from the findings of the study, the non-formal financial institutions seems important in savings mobilization, improvement in their activities could assist more in savings mobilisation for the ultimate development of the Nigerian economy.

The result further reveals that the mean savings of the respondents was N4,132.83, indicating that an individual, under normal circumstances, would be able to save up to this amount per annum. Any amouri less than this means that the person's savings are low while above it will show that an individual's savings are high or above average of that community.

\section{SOCIO-ECONOMIC CHARACTERISTICS AND SAVINGS METHOD}

\subsubsection{Age}

The age (in years) of the respondents was compared with methods of savings utilized. This is presented in table 2 . The result shows that, the most popular savings method is $t^{2}$ Osusu clubs. Although, most of the farmers claimed they patronize more than one savings institution, the one used most or the dominant institution is reported. Quite a large number of the farmers in the 31-40 year age bracket and those older than 40 years seemed to save more than others. This could be because they constitute the productive groups.

\subsubsection{Sex}

The sex of the farmers was also assessed in relation to their savings bchaviour. There was less participation of women in the use of all the available methods. This may be due to cultural bias on women in taking decisions on things affecting them, such as deciding to save money, or the choice of institution to patronize. Some women operate joint savings with their husbands, in which case, the choice may be that of the husband as the decision maker of the household. Nevertheless, both women and men lend to patronize asusu clubs more than any other savings institutions. Interestingly, more men save with co-operative societies, (12.94 percent) than women (10.59 percent). Women are shown to patronize the banks ( 11.76 percent) more than men $(9.41$ percent).

\subsubsection{Educational Level}

The level of education of farmers has been identified as one of the determining factors in their ability to accept and adopt new technologies that lead to high food production and increased capital formation. The result of this study reveals that education plays a significant role in the choice of modern savings method by the respondents. A greater number of those who use local chubs (Osusu) are without any formal education, while there is increased use of co-operative societies and banks among the graduates from tertiary institutions (Table 2). This could be attributed to their ability to overcome the bureaucracy involved in using modern banking facilities.

\subsubsection{Household Size}

The size of a household may influence the method of savings adopted by the saver as well as the amount saved. Results presented in table 2 revealed that houscholds with $1-5$ people used more of co-operative societies followed by the osusu clubs (11.76 percent of the households). The larger households tended to concentrate on the local savings clubs than other methods. The reason could be the availability of these clubs in almost every community in the study area and the ease of participating and saving in such clubs. This result tend to re-

emphasize the need for savings mobilization systems that are fashioned to meet the peculiar needs of the target population.

\subsubsection{Households' level of Income}

The income of households was estimated based on the income from farming and non-farming activities. The results revealed that the mean inçome per household was N4640 and about 21 percent of the farmers were found in this group. This implies that this is the threshold level or the amount that can conveniently be kept aside (save) by the people. Those above the average could be regarded as higher earners and they are expected to save more. The middle income earners are those within the average level N4640, while those lower than this are the low income earners (Table 2). Following this line of reasoning then only about 19 percent of the farmers could be considered high income earners while about 60 percent were low income earners in the study area.

\subsection{SAVINGS METHOD AND FOOD PRODUCTION}

\subsubsection{Crop Production}

This study has as one of its objectives, to examine the relationship between savings methods and agricultural production in the area. This was considered with respect to savings method, crop and livestock outputs. The results 


\section{Table 2: FARMERS' SOCIO-ECONOMIC CHARACTERISTICS AND} SAVINGS INSTITUTIONS PATRONISED

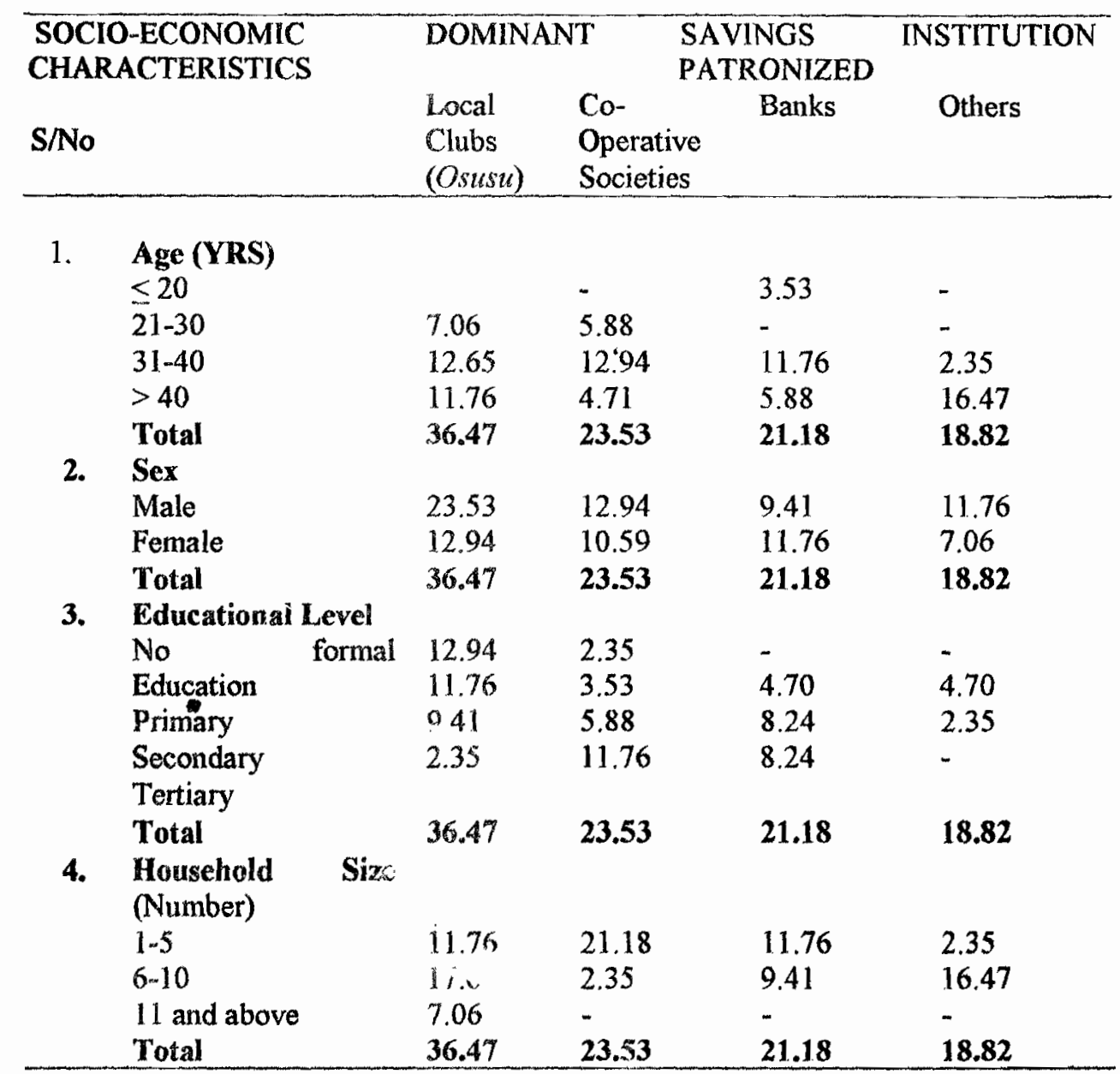

N/B: Figures are in percentages.

Table 3: $\quad$ DISTRIBUTION OF FARMERS BY INCOME LEVEL

\begin{tabular}{llllll}
\hline Income Group (N) & $\begin{array}{l}\text { Number } \\
\text { Respondents }\end{array}$ & of Percentage (\%) & $\begin{array}{l}\text { Total Income } \\
(\mathrm{N})\end{array}$ & $\begin{array}{l}\text { Dominant } \\
\text { Mcthod }\end{array}$ & Savings \\
\hline$\leq 500$ & 9 & 10.59 & 2,728 & Osusu \\
$500-1,999$ & 22 & 25.88 & 10,043 & Osusu \\
$2,000-2,999$ & 5 & 5.88 & 6,$77 ; 7$ & Co-operative Societics \\
$3,000-3,999$ & 15 & 17.65 & 76,245 & Co-operalive Socictics \\
$4,000-4,999$ & 18 & 21.18 & 83,500 & Banks \\
5,000 and above & 16 & 18.82 & 154,134 & Others \\
Average & - & - & 4640.08 & \\
Household Income & & & & \\
Total & 85 & 100.00 & 394,407 & \\
\hline
\end{tabular}

are as presented in table 4 . Findings showed that twenty respondents (23.53 percent) in cooperative societies have a tolal crop output of 6,333 tonnes. This group recorded the highest output per person of 316.7 tonnes. This was followed by banks' customers with a total output of 4731 tonnes and 262.3 tonnes per person. This remarkable performance could be indicative of better technical advirs and financial support form the sources. The local clubs, though with higher number of respondents and higher total output, have rather low output per person of 212,4 tonnes.

\subsubsection{Livestock Output}

The distribution here was bascd on the number of animals produced by the respondents who saved by varicus savings methods. The 
Table 4: $\quad$ SAVINGS METHODS AND CROP OUTPUT

\begin{tabular}{lllll}
\hline S/No & Savings method/institution & $\begin{array}{l}\text { Percentage of } \\
\text { total Respondents }\end{array}$ & $\begin{array}{l}\text { Total output } \\
\text { (Tonnes) }\end{array}$ & $\begin{array}{l}\text { Output per person } \\
\text { (Tonnes) }\end{array}$ \\
\hline 1 & Local Clubs (Osusu) & 36.47 & 6,585 & 212.4 \\
2 & Co-operative Socicties & 23.53 & 6,333 & 316.7 \\
3 & Banks & 21.18 & 4,731 & 262.3 \\
4 & Others & 18.82 & 2,334 & 145.8 \\
\hline
\end{tabular}

Table 5: $\quad$ SAVINGS METHODS LIVESTOCK OUTPUT

\begin{tabular}{lllll}
\hline S/No & Savings method/institution & $\begin{array}{l}\text { Percentage of } \\
\text { total Respondents }\end{array}$ & $\begin{array}{l}\text { Total oulput } \\
\text { (Tonnes) }\end{array}$ & $\begin{array}{l}\text { Output per person } \\
\text { (Tonnes) }\end{array}$ \\
\hline 1 & Local Clubs (Osusu & 36.47 & 5.471 & 176.5 \\
2 & Co-operative Societies & 23.53 & 3,950 & 197.5 \\
3 & Banks & 21.18 & 4,471 & 248.4 \\
4 & Others & 18.82 & 1,521 & 95.1 \\
\hline
\end{tabular}

Table 6: RESULTS OF THE MULTIPLE REGRESSION OF THE DOUBLE-LOG EQUATYON

\begin{tabular}{llll}
\hline S/No & Independent Variables & Coeff ients & I-Ratio \\
\hline 1 & Constant & 2.3991 & \\
2 & Al & 3.3415 & $2.2885^{* * *}$ \\
3 & HS & -0.1443 & $-2.3038^{* * *}$ \\
4 & DSI & 0.0131 & 0.2507 \\
5 & FNE & -2.3379 & $-9.5773^{* * *}$ \\
$\mathrm{R}^{2}$ & $=0.7045$ & & \\
F-ratio & $=47.6774^{* * *}$ & & \\
S.E. & $=0.4804$ & & \\
D.W. & $=2.3250$ & & \\
\hline
\end{tabular}

\section{*** Significant at 1 percent}

\section{** Significant at 5 percent}

organised savings institutions such as banks and co-operative societies recorded the highest output per person than other methods and institutions. The rcason for this is probably due to the reasonable financial support that could be rendered by the banks as compared to the fundings from other sources.

\subsection{REGRESSION ANALYSIS RESULTS}

In order to identify those factors which impact on savings, a regression analysis was carried out. Of the four functions estimated (linear, semi-log, exponential and double $\log$ ),

the double logarithmic form was selected as the Icad equation based on economic, statistical and econometric criteria. The result is given in rable 6.

The $R^{2}$ of 0.7045 suggests that about 70 F. .ent of the variation in the savings of the rural households is accounted for by the independent variables: houscholds' income, family size, distance to the savings institutions, and family expendilures. The remaining 30 percent are taken care of by the factors not considered in the model. An F-test shows that the equation is significant at 1 percent level of probability. Both income and family expenditures are significant at 1 percent level. Income is positive and significant while expenditure is negative and significant as well. This shows that income is directly related to savings while expenditure is negatively related to savings. This goes to confirm the existing belief that the amount of money an individual would be willing to save depends on his income and the level of his expenditure. The fanily size (FS) has a negative co-efficient but significant at 5 percent probability level. This indicates that larger the number of people in each houschold, the smaller the amount that will be saved from houscholds" disposable income. All other things being equal, large households are expected to save little from their income due to high consumption expenditure compared to the houscholds with fewer number of people.

In specific terms, the result shows that a 10 percent increase in income will raise savings by 33.415 percent while a 10 percent increase 
in the household size will reduce savings by 14.43.

The negative impact of household expenditure is however, greater than that of household size while the positive effect of household income has more impact on savings than the distance from savings institutions

\section{CONCLUSION AND \\ RECOMMENDATIONS}

The focus of this study was to investigate the savings behaviour of rural farmers. For savings to take place, appropriate savings mobilization is necessary. And, mobilization is effective only when efficient savings methods are used. Hence, savings method is an important factor to consider by ruralites in deciding how and when to save and how much to save. Il also enhances effective utilization of savings for higher productivity, which is the precursor for capital accumulation in the nural areas.

The results of the anayses indicate that other factors that affect savings behaviour of rural farmers inciude: the houscholds' incomes, households' size, distance to savings institutions and expenditure of the households. It is believed that if adequate measures are put in place to boost farmers' income, they would increase their savings. Since income has been found to be a major determinant of savings, there is the urgent need to creatc the enabling environment for farmers to earn more inconc so as to improve on their savings. This could come through appropriate pricing policies, adequate storage facilities which would enable farmers to store and dispose of their produce at appropriate time and at prices that are commensurate with the production cost. Also appropriate savings methods should be put in piaw to effect grassroots savings mobilization. The organised savings methods should be adapted to suit the peculiarities of the local environment. In this way, rural savings can be enhanced for sustainable agricullural production.

We are grateful to Mr. N. Ekweme for field assistance

\section{REFERENCES}

Baro, R.J. and Sala-i-Martin X 1990. Economics growth and Convergence across the United States. NBES Working Paper, No. 3419, Cambridge-Massachusetts: National Bureau of Economic Research 1991 "Convergence Across States, and Regions" Brookings Papers on Economic Activity p. 107-158.

Cass, D., 1965. Optimum Growth in an Aggregative Model of Capital Accumulation. Review of Economic Studies, 32:233-240.

Ijere, M.O., 1992. Promoting Local Govermment through Community setting, Discussion Paper. $1^{\text {st }}$ Amiversary of National
Board for Commuuity Banks. Abuja.

Iniodu, P.U. and Ukpak A. M. , 1996. The Relevance of Rural Finance for Efticient Management of $\Lambda$ gricultural Production in Post Adjustrincm, Nigeria. $\Lambda$ paper prevented at the Nigerian Economic Society (NES) Conference, Uyo.

Koopmans, T.C. , 1965. On the Concept of Optimal Growth, The Fconomic Approach to Development Planning Amsterdam: Nortli-[ Lolland.

Mlambo, K. and Elhiraika A., 1997. Macroconomic Policies and Private Saving and Investment in $\mathrm{SADC}$ Countries: An Empirical Analysis. Paper presented at the $3^{\text {rd }}$ Biennial Conference on African Issues. International Conference Centre, Benin Republic, January.

Ojo. M.O. and Osakwe, O. . 1984. An Appraisal of Public Sector Financing of Agricultural Development in Africa with Particular reference to Nigeria. Central Bank of Nigeria Economic and Financial Review. 24(2):33-41.

Olayide, S.O., Ogunfowora, O., Essang, S.M.and Idachaba, F.S., 1981. Elements of Rural Econonics, University Press-Ibadan, Nigeria. Pp: 203-209.

Patrick, R. , 1966. Financial Development and Econonic growth in underdeveloped Countries. Economic Development and Cultural Change $14: 179-189$.

Poster, IJ., 1966. The Promotion of Banking Habit and Economic Development. Jourual of Development Studies 3: 55 . 70

Ramsey, F.P. ,1928. $\wedge$ Mathematical Theory of Saving. Fconomic Journal, 38: 543-559.

Solow, R.M. 1956. A Contribution to the Theory of Economic Growth. Quarterly Journal of Economics, 70: 65-94.

Tella, S.A. 1998. Effect of Commercial Banks' Investment Potenial in Rural Nigeria: An Investigation, In: Rekindling Investment for Economic Development in Nigeria. Nigeria Ecoumic Society Conference Proceeding, Kano.

Umoh, G.S. 1998. Rural Financial Markets, Investment and Sustainable Rural Development in Nigeria. In: Rekindling Investment for Economic Development in Nigeria, Nigeria Economic Society Conference Proceeding, Kano. 